\title{
Significance of atmospheric deposition to freshwater ecosystems in the southern Iberian Peninsula
}

\author{
Rafael Morales-Baquero' ${ }^{1}$, Elvira Pulido-Villena, Otilia Romera, Eva Ortega-Retuerta, \\ Jose $\mathrm{M}^{\mathrm{a}}$ Conde-Porcuna, Carmen Pérez-Martínez and Isabel Reche \\ Departamento de Ecología e Instituto del Agua. Universidad de Granada, 18071 Granada, Spain. \\ ${ }^{1}$ Corresponding autor (rmorales@ugr.es)
}

\begin{abstract}
SUMMARY
The Iberian Peninsula is close to the Saharan Desert, which is the biggest source of atmospheric aerosols of the World. Currently, it is recognized that atmospheric deposition of aerosols over ecosystems is a significant source not only of elements with gaseous phases but also of rock-derived ones. In the last years we have been quantifying the atmospheric flux of elements and substances of biogeochemical interest on the aquatic ecosystems of the South Iberian Peninsula, and their impact on their functioning and structure. The results we are obtaining indicate that atmospheric contribution of $\mathrm{P}$ and $\mathrm{Ca}$ are essential to explain the functioning of high mountain lakes, and that atmospheric input of organic matter partially supports the pelagic food web of these ecosystems. In this article we offer a summary of some of the results obtained to date.
\end{abstract}

Key words: atmospheric deposition; phosphorus; nitrogen; calcium; soluble organic matter; lakes.

\section{RESUMEN}

La Península Ibérica está próxima al Desierto del Sahara que es la mayor fuente de aerosoles atmosféricos del Planeta. Actualmente, se reconoce que la deposición de aerosoles sobre los ecosistemas es una entrada significativa no sólo de elementos con fases gaseosas sino, también, de elementos derivados de rocas. En los últimos años hemos estado cuantificado el flujo atmosférico de elementos y sustancias de interés biogeoquímico sobre los ecosistemas acuáticos del sur de la Península Ibérica y el impacto sobre su funcionamiento y estructura. Los resultados que estamos obteniendo indican que los aportes atmosféricos de P y Ca son esenciales para explicar el funcionamiento de los lagos de alta montaña y que las entradas atmosféricas de materia orgánica sostienen parcialmente las redes tróficas pelágicas de estos ecosistemas. En este artículo ofrecemos un resumen de algunos de los resultados obtenidos hasta ahora.

Palabras clave: deposición atmosférica; fósforo, nitrógeno, calcio, materia orgánica soluble, lagos.

\section{INTRODUCTION}

Biogeochemical cycles impose strong restrictions to the organization of the Biosphere (Margalef, 1997). Therefore, Ecology needs to understand the causes and consequences of the global mobilization and distribution of elements. In this sense, the atmosphere is a major component of the Biosphere (sensu Vernadsky) as well as a pathway throughout which elements can be mobilized among ecosystems. However, we are far from having a complete comprehension of its role in Biogeochemistry.

Traditionally, the atmosphere has been considered the main source of elements with gaseous phases, such as $\mathrm{N}$, for terrestrial and aquatic ecosystems. By contrast, atmospheric contribution of rock-derived elements, such as $\mathrm{P}$ or $\mathrm{Ca}$, has been considered of minor relevance, highlighting the role of weathering inputs and sediment releases particularly in Limnology. This paradigm has prevailed over decades in studies on nutrient budgets in fresh-water ecosystems (Rodhe, 1948; Vollenweider, 1968, 1975, 1976). Due to anthropogenic activity, atmospheric nitrogen deposition in the Northern hemisphere significantly increased in the 70s and 80s and its effects on lake chemistry were intensely studied (Sullivan et al. 1990, Stoddard et al. 1999), whereas atmospheric inputs of phosphorus were not considered. 
Currently, it is well established that the atmosphere can mobilize amazing quantities of dust from the arid areas of the world (Schlesinger, 1997), and the role of the atmosphere as a vehicle for rock-derived elements has been recently revindicated (Chadwik et al., 1999). These authors found that the tropical ecosystems of Hawaii depend critically on phosphorus supplied by the atmosphere coming from the Central Asian Desert. At a global scale, the Sahara Desert is the largest arid area in the world and, consequently, it is the origin of the largest loads of dust to the atmosphere (D'Almeida, 1986). This dust is transported towards the Atlantic by the predominant westerly winds and towards the Mediterranean basin influenced by the presence of cyclones (Moulin et al., 1997).

Saharan dust contains high quantities of particulate matter, soluble minerals and organic carbon (Talbot et al., 1986). The effects of dust deposition in aquatic and terrestrial ecosystems are now receiving attention (Ridame and Guieu 2002; Okin et al., 2004) and there is a considerable interest in assessing the effects of dust deposition on marine ecosystems (Guerzoni et al. 1999; Herut et al., 1999, 2002; Lenes et al., 2001). A particular scientific effort has been done to determine the availability of dust-derived $\mathrm{P}$ to primary producers (Migon and Sandroni, 1999; Ridame and Guieu, 2002; Markaki et al., 2003). Although the potential relevance of atmospheric $\mathrm{P}$ deposition for freshwater ecosystems has been previously exposed (Peters, 1977), the effects of $P$ atmospheric inputs on lake biogeochemistry have been scarcely studied (Gibson el al, 1995).

Every year, the Iberian Peninsula receives intrusions of air masses loaded with dust from the Sahara Desert (Querol et al., 2003). Their deposition rates are poorly known and published data comes mainly from the Northeast of the Iberian Peninsula and is linked to rainfall (Camarero and Catalan, 1996; Avila et al., 1997). Nevertheless the Iberian Peninsula shows a strong gradient in the rainfall with minimum values in the Southeast where the dry deposition is predominant. During the last years, we have been developing a program to study wet and dry deposition in the Southern part of the Iberian Peninsula, and

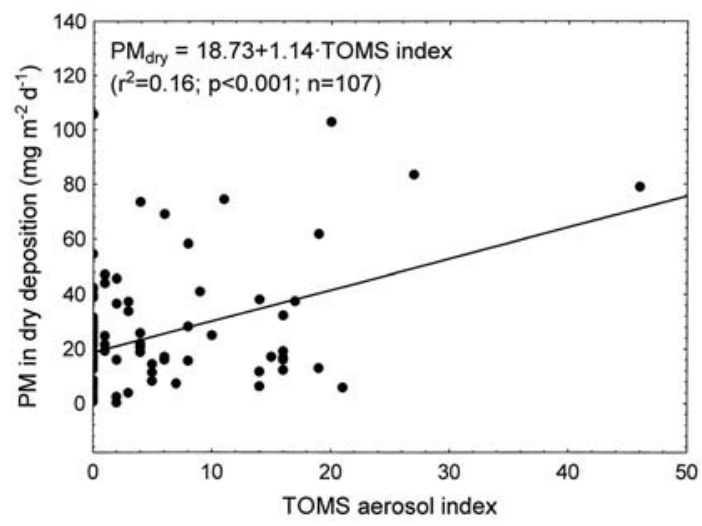

Figure 1. Relationship between TOMS aerosol index (NASA, Goddard Space Flight Center), as a surrogate of dust in the troposphere, and the dry PM collected weekly at $1000 \mathrm{~m}$ a.s.1. Despite that the TOMS aerosol index only provides valid values of dust at altitudes over $2000 \mathrm{~m}$ above ground, it is possible to establish a direct connection between the dust content at medium and high altitudes in the troposphere and the PM collected at ground level. Dust at these altitudes is mainly due to massive dust inputs originated in the Sahara Desert (after Morales-Baquero et al., 2006). Relación entre el índice de aerosoles TOMS (NASA, Goddard Space Flight Center), indicador del polvo en la troposfera, y el material particulado (PM) seco recogido semanalmente a $1000 \mathrm{~m}$ snm. A pesar de que el índice TOMS sólo proporciona valores válidos de polvo por encima de $2000 \mathrm{~m}$ sobre el nivel del suelo, se puede establecer una relación directa entre el contenido de polvo en niveles medios y altos de la troposfera y el PM recogido a nivel del suelo. En las altitudes citadas, el polvo procede principalmente de las inyecciones masivas originadas en el Desierto del Sahara (de Morales-Baquero et al., 2006).

their effects on biogeochemistry of high mountain lakes and reservoirs of this area. Our goal is to quantify the atmospheric inputs of elements and substances relevant for the biogeochemical cycles of aquatic ecosystems, as representative of atmospheric deposition in the Southwest Mediterranean, and to establish direct links between such inputs and freshwater ecosystem responses. Here, we offer a summary of some of the more relevant results obtained to date.

\section{DEPOSITION OF PARTICULATE MATTER (PM)}

Data on dry and wet deposition obtained on a weekly basis during two years at $1000 \mathrm{~m}$ and at $2900 \mathrm{~m}$ a.s.1. (only ice-free periods), conforms to a Mediterranean regional pattern with gro- 
wing values, as distances from Sahara are shorter and closer to the Eastern latitudes (Goudie and Middleton, 2001). The mean PM total (dry + wet) deposition in Sierra Nevada at $1000 \mathrm{~m}$. (11.2 $\mathrm{g} \mathrm{m}^{-2} \mathrm{yr}^{-1}$ Morales-Baquero et al., 2006) is higher than the values reported for Catalonia (Montseny) (5.3 $\mathrm{g} \mathrm{m}^{-2} \mathrm{yr}^{-1}$, Avila et al, 1997) and the Alps (0.2 to $0.4 \mathrm{~g} \mathrm{~m}^{-2} \mathrm{yr}^{-1}$ Wagenbach and Geis, 1989; De Angelis and Gaudichet, 1991), similar to the values registered in Corsica (12-12.5 $\mathrm{g} \mathrm{m}^{-2} \mathrm{yr}^{-1}$, Bergametti et al., 1989; Löye-Pilot et al., 1986) and lower than those reported for the East Mediterranean area (36 to $72 \mathrm{~g} \mathrm{~m}^{-2} \mathrm{yr}^{-1}$ Herut and Krom, 1996). Although rainfall can washout high quantities of PM, the contribution of dryfall to the annual total PM inputs registered in Sierra Nevada (79\%) was much higher than the wet deposition, emphasizing the importance of dry deposition in areas where the rain is scarce (Morales-Baquero et al., 2006).

Several evidences point out that Saharan dust dominates PM deposition in the Southwest
Iberian Peninsula: 1) dry PM deposition exhibited a similar seasonal pattern to Saharan dust export toward the Mediterranean basin, which is characterized by maximum values particularly during spring and summer (Moulin et al. 1997); 2) there was a positive relationship between dry PM deposition and TOMS aerosol index (Fig. 1), which is a suitable estimator of Saharan dust content in the atmosphere (Chiapello et al., 1999); and 3) we registered higher PM deposition at $2900 \mathrm{~m}$ than at $1000 \mathrm{~m}$ which is consistent with the dynamics of Saharan dust transport, with maximum loads mobilized between 1500 and $4000 \mathrm{~m}$ (Talbot et al., 1986). Furthermore, the analysis of dust deposition depending on the air masses' origin, determined by using backward trajectories analysis (HYSPLIT model, NASA) have clearly shown higher dust deposition when the air masses come from the South or Southwest rather than from other directions (Fig. 2). All these results reveal a significant and regular atmospheric transport of material from the African Continent to the South of the Iberian Peninsula.

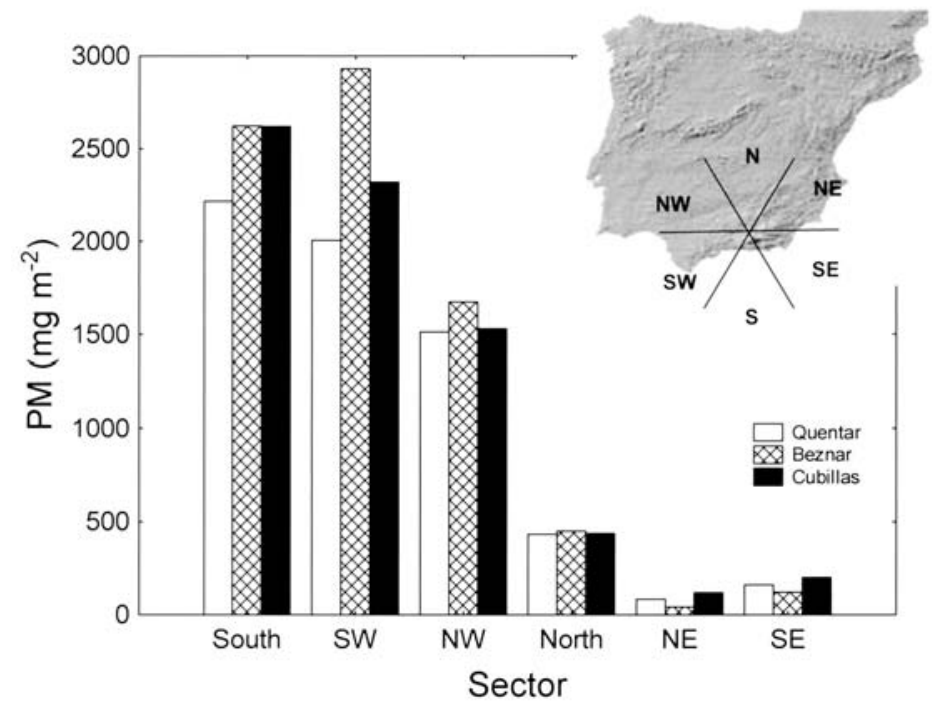

Figure 2. Synchronous measurements of dry PM deposition in three collectors located in sites up to $40 \mathrm{~km}$ distant in the Granada province and near three studied reservoirs. The values are cumulative data from weekly measurements during spring and summer of 2004 segregated according to the origin of the air masses for each corresponding week. Origins were determined by analysing 5-day backward trajectories at $3000 \mathrm{~m}$ asl using the HYSPLIT model (NOAA, Air Resources Laboratory). It is evident that PM deposition is higher when air masses arrive from the South or Southwest. Medidas sincrónicas de la deposición seca de material particulado (PM) en tres colectores situados en localidades separadas hasta en $40 \mathrm{~km}$ dentro de la Provincia de Granada y cercanos a tres embalses en estudio. Los valores son datos acumulados de medidas semanales durante la primavera y verano de 2004, separados de acuerdo con el origen de las masas de aire en cada semana. Los orígenes se determinaron analizando retrotrayectorias de 5 días a $3000 \mathrm{~m}$ snm calculadas aplicando el modelo HYSPLIT (NOAA, Air Resources Laboratory). Es evidente que la precipitación de PM es más elevada cuando las masas de aire llegan del Sur o Suroeste. 


\section{NITROGEN AND PHOSPHORUS DEPOSITION}

Saharan dust contains significant quantities of phosphorus. In fact, this source accounts for 30$40 \%$ of the total atmospheric flux of phosphorus into the Northwestern Mediterranean (Guieu et al., 2002). In Sierra Nevada the mean deposition of total phosphorus (TP) was $513 \mu \mathrm{mol} \mathrm{m}^{-2} \mathrm{yr}^{-1}$ (Morales-Baquero et al., 2006), that is similar to deposition attributed to Saharan dust in Corsica (about $500 \mu \mathrm{mol} \mathrm{m}{ }^{-2} \mathrm{yr}^{-1}$, Bergametti et al., 1992), lower than the deposition measured in the East Mediterranean $\left(1300 \mu \mathrm{mol} \mathrm{m}^{-2} \mathrm{yr}^{-1}\right.$, Herut et al., 1999), and higher than in Catalonia $(100 \mu \mathrm{mol}$ $\mathrm{m}^{-2} \mathrm{yr}^{-1}$-only wet deposition-, Avila et al., 1998). The $\mathrm{P}$ deposition in our studies showed a similar pattern to PM deposition, with maximum values in spring and summer. In fact, we found a significant correlation between PM deposition and TP deposition $(n=107 ; r=0.45 ; p<0.001)$.

In contrast, total nitrogen (TN) deposition (39.6 $\mathrm{mmol} \mathrm{m}^{-2} \mathrm{yr}^{-1}$, Morales-Baquero et al., 2006) was always lower than other sites from the Mediterranean basin $\left(55 \mathrm{mmol} \mathrm{m}^{-2} \mathrm{yr}^{-1}\right.$ in the Northwest (Guerzoni et al., 1999) and about $50 \mathrm{mmol} \mathrm{m}^{-2} \mathrm{yr}^{-1}$ in the East (Herut et al., 2002; Markaki et al., 2003), only inorganic fractions in both cases), making the anthropogenic impact over that area evident since $\mathrm{N}$ deposition is mostly linked to anthropogenic activity (Driscoll et al., 2003). TN deposition did not show a clear season pattern and was not correlated to PM deposition. In addition, wet deposition contributed more than $50 \%$ to $\mathrm{N}$ inputs, whereas most $\mathrm{P}$ inputs over our study area were linked to dry deposition (72\%). The differences in the $\mathrm{N}$ and $\mathrm{P}$ inputs are also reflected in the molar TN:TP ratio of the atmospheric deposition, which varies seasonally from values as low as 11.9 in spring or summer to values $>100$ in fall or winter.

The atmospheric inputs coming from Saharan dust appear to affect the biogeochemistry of the high mountain lakes from Sierra Nevada. The relatively high atmospheric inputs of $P$ during summers were previously suggested as the responsible for the enhancement of $\mathrm{P}$ deficiency, as the summer progress, in lakes

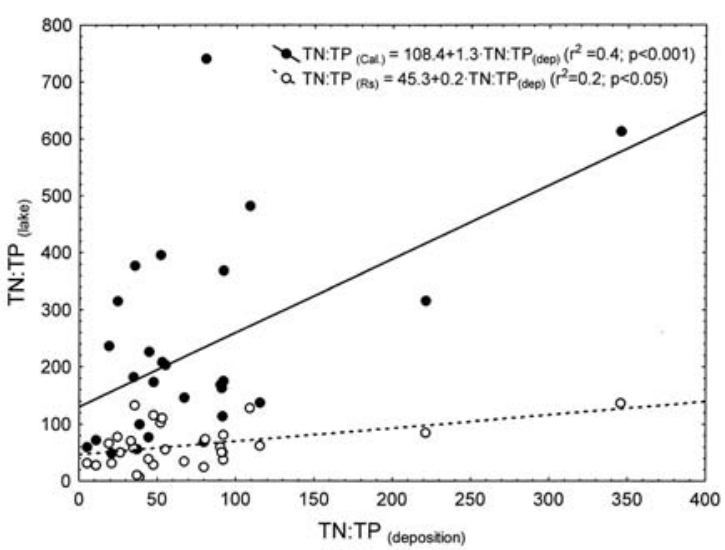

Figure 3. Relationships between the TN:TP molar ratio of the atmospheric deposition and the TN:TP molar ratio of the water column in La Caldera and Río Seco lakes. Although the atmospheric TN:TP molar ratio significantly affects both lakes, the influence on La Caldera nutrient status is steeper than that on Río Seco (after Morales-Baquero et al., 2006). Relaciones entre la razón molar TN:TP de la deposición atmosférica y la razón molar TN:TP de la columna de agua en las lagunas de La Caldera y Río Seco. Aunque la relación molar TN:TP atmosférica afecta significativamente a ambas lagunas, la influencia en los nutrientes de La Caldera es más acusada que en Río Seco. (de Morales-Baquero, et al. 2006).

with bigger catchments areas (MoralesBaquero et al., 1999). The lakes with relatively smaller basins reflect the atmospheric N:P ratio more closely than the inputs from watersheds. In fact, $\mathrm{N}: \mathrm{P}$ ratios of atmospheric inputs significantly relate to $\mathrm{N}: \mathrm{P}$ ratios of lakes, affecting nutrient status (Morales-Baquero et al, 2006) (Fig. 3). In addition, we found a direct connection between atmospheric TP input and the response of phytoplankton (Morales-Baquero et al., 2006) (Fig. 4), demonstrating the importance and bioavailability of the $\mathrm{P}$ delivered from the atmosphere in natural conditions.

\section{CALCIUM DEPOSITION}

It is well known that Saharan dust contains high quantities of calcium carbonate (Löye-Pilot et al. 1986), which significantly increases the $\mathrm{pH}$ of rainwater and its deposition is an important input of $\mathrm{Ca}$ to terrestrial ecosystems (Avila et al., 1997). The mean total atmospheric inputs of calcium at $1000 \mathrm{~m}$ registered in Sierra Nevada 


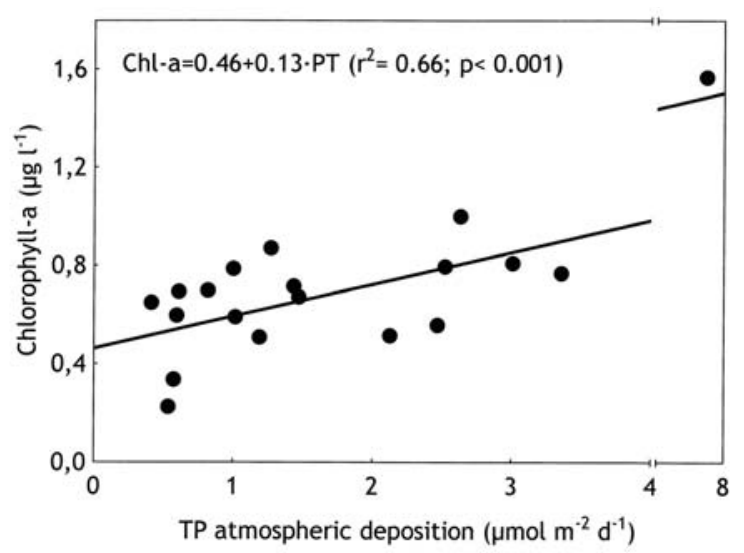

Figure 4. Relationship between atmospheric deposition of total phosphorous (TP) and Chlorophyl-a (Chl a) in $\mathrm{La}$ Caldera Lake. Each point represents the weekly input of TP (dry + wet) against the water column integrated Chl-a values at the end of the corresponding week. TP deposition explains $66 \%$ of Chl-a variability (after Morales-Baquero et al., 1966). Relación entre la deposición atmosférica de fósforo total (TP) y el contenido en clorofila a (Chl a) de la laguna de La Caldera. Cada punto representa la entrada semanal de TP (seco + húmedo) frente a los valores de Chl a integrados para la columna de agua al final de la semana correspondiente. La deposición de TP explica el $66 \%$ de la variabilidad de la Chl a (de Morales-Baquero, et al. 2006).

(39.2 $\mathrm{mmol} \mathrm{m}^{-2} \mathrm{yr}^{-1}$; Pulido-Villena et al., 2006) were slightly higher than those reported for the Northeastern Iberian Peninsula, an area also influenced by Saharan dust inputs (24.8 $\mathrm{mmol} \mathrm{m}^{-2} \mathrm{yr}^{-1}$; Avila et al., 1997; 1998), and clearly higher than the reported for Northern Europe $\left(6.1 \mathrm{mmol} \mathrm{m}^{-2} \mathrm{yr}^{-1}\right.$; Hultberg and Ferm, 2004). Like P deposition, Ca dry deposition was prevalent (64\% of total deposition), and showed the same seasonal pattern of PM dry deposition. Consequently, PM and $\mathrm{Ca}$ dry deposition were correlated $(\mathrm{r}=0.60 ; \mathrm{p}<0.001 ; \mathrm{n}=106)$. The influence of Saharan dust in Ca deposition is showed by the $50 \%$ mean increase when Saharan intrusions over the Iberian Peninsula occur (Fig. 5).

The atmospheric inputs of $\mathrm{Ca}$ are a determining factor for the $\mathrm{Ca}$ content in the Sierra Nevada lakes. We have recorded the Ca concentrations during three ice-free periods in two lakes: Rio Seco and La Caldera, with and without superficial outlets respectively. Ca concentration was always higher in La Caldera Lake $(107.6 \pm 1.1 \mu \mathrm{M})$ than in Río Seco Lake

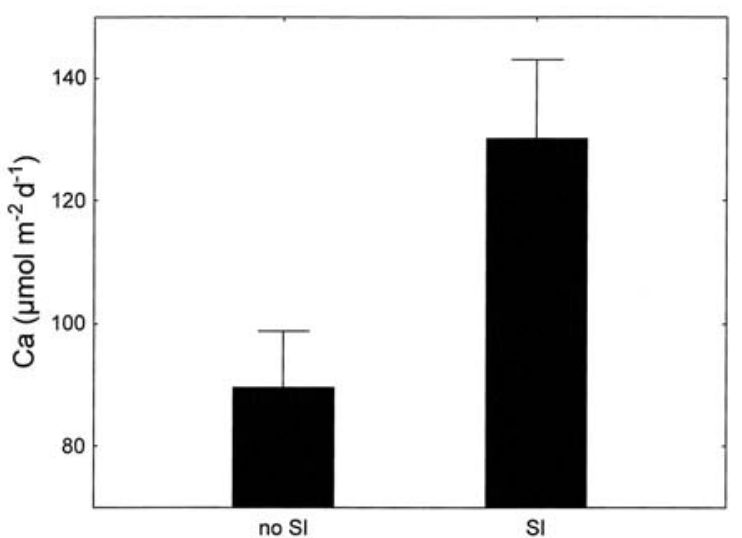

Figure 5. Weekly averages of Ca deposition for 2001 and 2002 at the $1000 \mathrm{~m}$ a.s.1. collector. Values are segregated depending on the existence ( 62 weeks) or not (42 weeks) of Saharan intrusions (SI) over the Iberian Peninsula (after Pulido-Villena, 2004). Promedios semanales de deposición de Ca recogidos durante 2001 y 2002 en el colector situado a 1000 m snm. Los valores se han separado de acuerdo con la existencia (62 semanas) o no (42 semanas) de intrusiones saharianas (SI) sobre la Península Ibérica (de Pulido Villena, 2004).

$(37.4 \pm 1.1 \mu \mathrm{M})$. Ca concentration in both lakes showed a significant synchronous dynamics $(\mathrm{r}=0.63 ; \mathrm{p}<0.001 ; \mathrm{n}=35)$. This fact suggests a climatic control, which could also be due to evaporative processes during summer. Nevertheless, analysing the in-lake variation of the ${ }^{18} \mathrm{O}$ isotope, as a surrogate for evaporation, and the total direct $\mathrm{Ca}$ deposition to lakes, it has been possible to establish that $\mathrm{Ca}$ deposition is positively affecting the $\mathrm{Ca}$ concentration in both lakes. Furthermore, a mass estimate of $\mathrm{Ca}$ inputs to lakes and basins, realized on an annual basis, showed that atmospheric inputs can fully explain the $\mathrm{Ca}$ concentrations found in both lakes (Pulido-Villena et al., 2006). Therefore, the atmospheric $\mathrm{Ca}$ deposition appears to be a key factor to understand the high $\mathrm{Ca}$ content (and related variables, e.g. the acidneutralizing capacity) of some lakes in Sierra Nevada in comparison with the central Europe high mountain lakes (MOLAR, 1999).

\section{ORGANIC MATTER DEPOSITION}

Among the soil components mobilized as aerosols by the atmosphere, there are important 


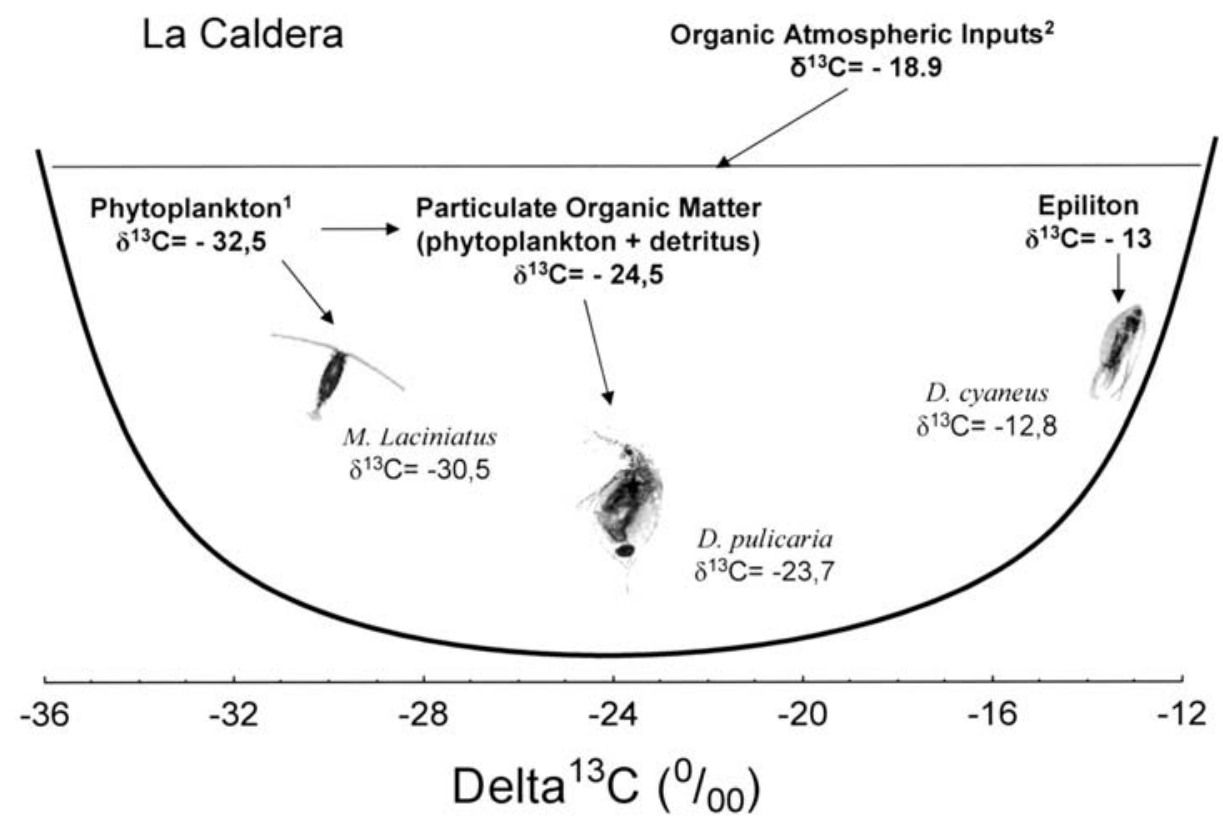

Figure 6. Food web interactions in La Caldera lake as deduced from a ${ }^{13} \mathrm{C}$ isotope analysis of their major components. The three crustacean species appear clearly segregated in their respective food sources. The significance of atmospheric inputs of organic Carbon is deduced from the high values of $\delta^{13} \mathrm{C}$ signature of POM in the lake (after Pulido-Villena et al., 2005). ${ }^{1)} \delta^{13} \mathrm{C}$ of phytoplankton for La Caldera was estimated using a fractionation factor of $20 \%$ and the values of $\delta^{13} \mathrm{C}$ of dissolved inorganic carbon measured by us. ${ }^{2}{ }^{1}{ }^{13} \mathrm{C}$ values for atmospheric inputs after Eglinton et al. (2002). Interacciones en la red trófica de la laguna de La Caldera según se deducen de un análisis del isótopo ${ }^{13} \mathrm{C}$ en sus principales componentes. Los tres crustáceos mayoritarios aparecen claramente segregados en sus respectivas fuentes de alimento. La importancia de las entradas atmosféricas de carbono orgánico se deduce de los altos valores de $\delta^{13} \mathrm{C}$ de la materia orgánica particulada (POM) en la laguna (de Pulido-Villena et al., 2005). ${ }^{1)} \mathrm{El} \delta^{13} \mathrm{C}$ del fitoplancton en La Caldera se estimó usando un factor de fraccionamiento del $20 \%$ y los valores del $\delta^{13} \mathrm{C}$ del carbono inorgánico disuelto medidos por nosotros. ${ }^{2)}$ Valores de $\delta^{13} C$ de las entradas atmosféricas según Eglinton et al. (2002).

quantities of particulate and water-soluble organic carbon (W-SOC) (Talbot et al., 1986). Its deposition rates and ecological effects are poorly known, although it has been reported that atmospheric wet deposition of W-SOC to oceans can be similar to the dissolved organic carbon (DOC) derived from global river discharge (Willey et al. 2000). The atmospheric deposition of W-SOC is expected to be very significant in oligotrophic high mountain lakes where these compounds have low concentrations $\left(<1 \mathrm{mg} \mathrm{l}^{-1}\right)$ but play important functions, such as the regulation of ultraviolet radiation attenuation (Laurion et al. 2000; Reche et al., 2001).

The total summer cumulative atmospheric deposition of W-SOC collected at $2900 \mathrm{~m}$ in Sierra Nevada was $20-\mathrm{mmol} \mathrm{m}^{-2}$, and about $50 \%$ of this quantity arrived with the dry deposition of PM. Total PM deposition showed a direct relationship with total W-SOC deposition $(\mathrm{r}=0.62 ; \mathrm{p}<0.001 ; \mathrm{n}=33)$ (Pulido-Villena, 2004). These rates demonstrate that there is a substantial input of organic carbon, potentially bio-available, from the atmosphere to Sierra Nevada lakes. In fact, an analysis of the pelagic food webs, using a stable isotope approach, showed that this source of carbon might be essential for the food-webs in these lakes (Pulido-Villena et al., 2005). Fig. 6 shows the carbon stable isotope signature of the pelagic food web of La Caldera Lake. $\delta^{13} \mathrm{C}$ of the zooplanktonic community revealed species-specific differences in their food sources, probably as a result of an ecological niche segregation. The cladoceran Daphnia pulicaria relied mainly on bulk particulate organic matter (POM) whose isotopic signature $\left(\delta^{13} \mathrm{C}=-24.5 \%\right.$ ) was heavier than that estimated for phytoplankton $\left(\delta^{13} \mathrm{C}=-32.5 \%\right)$. The most 
plausible explanation for this discrepancy is that POM was composed not only of phytoplankton (and derived biota and detritus) but also of terrestrial organic matter, which is usually enriched in ${ }^{13} \mathrm{C}$. Since the basin of La Caldera Lake is rocky, the atmospheric inputs of organic matter, mainly derived from Sahara, could explain the heavy signal of POM in La Cadera. In this regard, the measured atmospheric input of WSOC in La Caldera may represent as much as $33 \%$ of the dissolved organic carbon concentrations found in this lake (Pulido-Villena et al., 2005). Furthermore, a recent study by Eglinton et al. (2002) reported that the isotopic signature of total organic carbon in atmospheric dust derived from the Sahara Desert is especially heavy (c.a. $-18 \%$ ) suggesting the presence of biomass and burning residues derived from predominantly $\mathrm{C} 4$ vegetation accumulated in the soils.

The atmospheric inputs of organic matter can be a source of food not only for indiscriminate filter-feeding animals such as D. pulicaria, but also for bacteria. In fact, a bacteria culture enriched with atmospheric dust showed higher growth efficiency on atmospheric W-SOC than on lake DOC (Pulido-Villena, 2004). Therefore, the food webs of the high mountain lakes of Sierra Nevada can be partially supported by a source of energy originated in terrestrial ecosystems from other continents and whose transport is regulated by global atmospheric circulation patterns.

\section{MICROORGANISMS AS AEROSOLS}

Although the microbial component of aerosols is known since the $19^{\text {th }}$ century, it has not received attention up to the present decade. Aerosols can mobilize about $10^{18}$ cells per year (Griffin et al., 2002) and these air-transported microorganisms can survive long distances suspended in dust particles. However, their colonizing abilities and outcompeting success are almost unknown. The deposition, viability, and expansion of these invading microorganisms can affect the indigenous microbiota, particularly in remote lakes with high ecological value. In an ongoing project (ECOSENSOR, Fundación BBVA) we have selected remote lakes from the Arctic area, Antarctica, Patagonia, and high mountains to establish microbial biogeography patterns. We pretend to assess the role of the atmospheric long-range transport of microorganisms as a dispersal mechanism affecting microbial biodiversity patterns, since the spatial structure appears to contribute significantly to lake bacterial composition (Reche et al., 2005). Some preliminary experiments in our laboratory have also confirmed the existence of viable bacteria linked to dust deposition.

\section{CONCLUSIONS}

From the results obtained to date, it appears evident that the deposition of elements and compounds mobilized as aerosols by the atmosphere plays a significant role in the biogeochemistry of high mountain lakes from the Southern Iberian Peninsula. This deposition is related to dust exported from the Sahara desert on an annual basis, implying a regular intercontinental transfer of material. The deposition occurs mostly in dry form, and its effect on terrestrial and aquatic ecosystems needs to be addressed.

The dryfall of particulate matter is a climatic variable that, contrary to rainfall, has been scarcely considered. This variable is connected to global atmospheric circulation patterns such as the North Atlantic Oscillation (NAO). High positive NAO years involve high dust export from the Sahara to the Mediterranean basin (Moulin et al., 1997). The increase in the transport of aerosols that the recent models of climatic change have predicted, will probably lead to in an increase in the input of mineral nutrients and $\mathrm{W}$ SOC to freshwater ecosystems. In areas, such as the Mediterranean basin with long periods of absence of rainfall, the dryfall is continuously reaching aquatic ecosystems where the soluble components appear to have consequences, which we are now beginning to understand.

From Margalef's legacy two major ideas have emanated and inspired this ongoing research. First, that biogeochemical cycles impose strong 
restrictions to organization of the Biosphere, and second, that high mountain lakes are the finest sensors available to detect changes in the troposphere. We have now evidences that the atmosphere can supply both gaseous and rockderived elements essential for the biogeochemistry of Sierra Nevada high mountain lakes that are particularly sensible to variations in that supply. Since we are very grateful to the work of Margalef, these pages are a little tribute to him.

\section{ACKNOWLEDGEMENTS}

Financial support was provided by the projects CICYT AMB99-0541 and MCYT REN03-03038.

\section{REFERENCES}

AVILA, A., I. QUERALT-MITJANS \& M. ALARCÓN. 1997. Mineralogical composition of African dust delivered by red rains over northeastern Spain. Journal of Geophysical Research, 102: 21977-21996.

AVILA, A., M. ALARCON \& I. QUERALT. 1998. The chemical composition of dust transported in red rains. Its contribution to the biogeochemical cycle of a Holm oak forest in Catalonia (Spain). Atmospheric Environment, 32(2): 179-191.

BERGAMETTI, G., L. GOMES, E. REMOUDAKI, M. DESBOIS, D. MARTIN \& P. BUATMÉNARD. 1989. Present transport and deposition patterns of African dusts to the north-western Mediterranean. In: Paleoclimatology and Palaeometeorology: Modern and Past Patterns of Global Atmospheric Transport. M. Leinen and M. Sarnthein (eds.).: 227-252. NATO ASI Series, C, vol. 282

BERGAMETTI, G., E. REMOUDAKI, R. LOSNO, E. STEINER, B. CHATENET, \& P. BUATMÉNARD. 1992. Source, transport and deposition of atmospheric phosphorus over the northwestern Mediterranean. J. Atmos. Chem., 14: 501-513.

CAMARERO, L. \& J. CATALAN, J. 1996. Variability in the chemistry of precipitation in the Pyrenees (northeastern Spain): Dominance of storm origin and lack of altitude influence. $J$. Geophys. Res., 101: 29491-29498.

CHADWICK, O. A., L. A. DERRY, P. M. VITOUSEK, B. J. HUEBERT \& L. O. HEDIN.
1999. Changing sources of nutrients during four million years of ecosystem development. Nature, 397: 493-497.

CHIAPELLO, I., J. M. PROSPERO, J. R. HERMAN \& N. C. HSU. 1999. Detection of mineral dust over the North Atlantic Ocean and Africa with the Nimbus 7 TOMS. J. Geophys. Res., 104(D8): 9277-9291.

D'ALMEIDA, G. A. 1986. A model for Saharan dust transport. J. Clim. Appl. Meteorol., 25: 903-916.

DE ANGELIS, M., \& A. GAUDICHET. 1991. Saharan dust deposition over Mont Blanc (French Alps) during the last 30 years. Tellus, 43B: 61-67.

DRISCOLL C. T., D. WHITALL, J. ABER, E. BOYER, M. CASTRO, C. CRONAN, C. L. GOODALE, P. GROFFMAN, C. HOPKINSON, K. LAMBERT, G. LAWRENCE, \& S. OLLINGER. 2003. Nitrogen pollution in the northeastern United States: Sources, effects, and management options. Bioscience, 53: 357-374.

EGLINTON, T. I., G. EGLINTON, L. DUPONT, E. R. SHOLKOVITZ, D. MONTLUÇON \& C. M. REDDY. 2002. Composition, age, and provenance of organic matter in NW African dust over the Atlantic Ocean. Geochem. Geophys. Geosyst., 3: 10.1029/2001GC000269.

GIBSON, C. E., Y. WU \& D. PINKERTON. 1995. Substance budget of an upland catchment: the significance of atmospheric phosphorus inputs. Freshwat. Biol., 33: 385-392.

GOUDIE, A. S. \& N. J. MIDDLETON. 2001. Saharan dust storms: nature and consequences. Earth-Science Reviews, 56: 179-204.

GRIFFIN, D. W., C. A. KELlOGG, V. H. GARRISON, \& E. A. SHINN. 2002. The global transport of dust. American Scientist, 90: 230-237

GUERZONI, S., R. CHESTER, F. DULAC, B. HERUT, M. D. LOŸE-PILOT, C. MEASURES, C. MIGON, E. MOLINAROLI, C. MOULIN, P. ROSSINI, C. SAYDAM, A. SOUDINE \& P. ZIVERI. 1999. The role of atmospheric deposition in the biogeochemistry of the Mediterranean Sea. Progress in Oceanography, 44: 147-190.

GUIEU, C., M. D. LOŸE-PILOT, C. RIDAME \& C. THOMAS. 2002. Chemical characterization of the Saharan dust end-member: Some biogeochemical implications for western Mediterranean Sea. J. Geophys. Res., 10.1029/2001JD000582

HERUT, B., \& M. D. KROM. 1996. Atmospheric inputs of nutrients and dust to the SE Mediterranean. In: The impact of desert dust across the Mediterranean. S. Guerzoni and R. Chester (eds.).: 349-359. Kluwer. 
HERUT, B., M. D. KROM, G. PAN \& R. MORTIMER. 1999. Atmospheric input of nitrogen and phosphorus to the Southeast Mediterranean: Sources, fluxes and possible impact. Limnol. Oceanogr., 44(7): 1683-1692.

HERUT, B., R. COLLIER \& M. D. KROM. 2002. The role of dust in supplying nitrogen and phosphorus to the Southeast Mediterranean. Limnol. Oceanogr., 47(3): 870-878.

HULTBERG, H., \& M. FERM. 2004. Temporal changes and fluxes of sulphur and calcium in wet and dry deposition, internal circulation as well as in run-off and soil in a forest at Gårdsjön, Sweden. Biogeochemistry, 68: 355-363.

LAURION I, M. VENTURA, J. CATALAN, R. PSENNER \& R. SOMMARUGA. 2000. Attenuation of UV radiation in mountain lakes: factors controlling among- and within variability. Limnol Oceanogr., 45: 1274-1288.

LENES, J. M., B. P. DARROW, C. CATTRALL, C. A. HEIL, M. CALLAHAN, G. A. VARGO, R. H. BYRNE, J. M. PROSPERO, D. E. BATES, K. A. FANNING \& J. J. WALSH. 2001. Iron fertilization and the Trichodesmium response on the West Florida shelf. Limnol. Oceanogr., 46(6): 1261-1277.

LÖYE-PILOT, M. D., J. M. MARTIN \& J. MORELLI. 1986. Influence of Saharan dust on the rain acidity and atmospheric input to the Mediterranean. Nature, 321: 427-428

MARGALEF, R. 1997. Our Biosphere. Ecology Institute. Oldendorf/Luhe. 176 pp.

MARKAKI, Z., K. OIKONOMOU, M. KOCAK, G. KOUVARAKIS, A. CHANIOTAKI, N. KUBILAY \& N. MIHALOPOULOS. 2003. Atmospheric deposition of inorganic phosphorus in the Levantine Basin, eastern Mediterranean: Spatial and temporal variability and its role in seawater productivity. Limnol. Oceanogr., 48(4): 1557-1568.

MIGON, C. \& V. SANDRONI. 1999. Phosphorus in rainwater: Partitioning inputs and impact on the surface coastal ocean. Limnol. Oceanogr., 44(4): 1160-1165.

MOLAR Water Chemistry Group. 1999. The MOLAR Project: atmospheric deposition and lake water chemistry. Journal of Limnology, 58: 88106.

MORALES-BAQUERO, R., P. CARRILLO, I. RECHE, \& P. SÁNCHEZ-CASTILLO. 1999. The nitrogen:phosphorus relationship in high mountain lakes: effects of the size of catchment basins. Canadian J. Fish. Aquat. Sci., 56: 1809-1817.
MORALES-BAQUERO, R., E. PULIDO-VILLENA \& I. RECHE. 2006. Atmospheric inputs of phosphorus and nitrogen to the Southwest Mediterranean region: Biogeochemical responses of high mountain lakes. Limnol. Oceanogr., (in press)

MOULIN, C., C. E. LAMBERT, F. DULAC \& U. DAYAN. 1997. Control of atmospheric export of dust from North Africa by the North Atlantic Oscillation. Nature, 387: 691-694.

OKIN, G. S., N. MAHOWALD, O. A. CHADWICK, \& P. ARTAXO. 2004. Impact of desert dust on the biogeochemistry of phosphorus in terrestrial ecosystems. Glob. Biogeochem. Cycles 18: Art. No. GB2005. doi: 10.1029/2003GB002145.

PETERS, R. H. 1977. Availability of atmospheric orthophosphate. J. Fish. Res. Board Can., 34: 918924.

PULIDO-VILLENA, E. 2004. El papel de la deposición atmosférica en la biogeoquímica de lagunas de alta montaña (Sierra Nevada, España). Tesis Doctoral. Universidad de Granada. 296 pp.

PULIDO-VILLENA, E., I. RECHE \& R. MORALES-BAQUERO. 2005. Food web reliance on allochthonous carbon in two high mountain lakes with contrasting catchments: a stable isotope approach. Can. J. Fish. Aquat. Sci. 62: 2640-2648.

PULIDO-VILLENA, E., I. RECHE \& R. MORALESBAQUERO. 2006. Significance of atmospheric inputs of calcium over the Southwestern Mediterranean region: high mountain lakes as tools for detection. Global Biogeochemical Cycles, (in press)

QUEROL, X., A. ALASTUEY, S. RODRÍGUEZ, M. M. VIANA, B. ARTIÑANO, P. SALVADOR, E. MANTILLA, S. G. D. SANTOS, R. F. PATIER, J. D. L. ROSA, A. D. S. L. CAMPA \& M. MENÉNDEZ. 2003. Estudio y evaluación de la contaminación atmosférica por material particulado en España. Informes finales. Instituto Jaume Almera-CSIC, ISCIII, CIEMAT, Universidad de Huelva, Universidad del País Vasco. Ministerio de Medio Ambiente. 36 pp.

RECHE I, E. PULIDO-VILLENA, J. M. CONDEPORCUNA \& P. CARRILLO. 2001. Photoreactivity of dissolved organic matter from high mountain lakes of Sierra Nevada, Spain. Artic. Antartic and Alpine Research, 33: 426-434.

RECHE, I. E. PULIDO-VILLENA, R. MORALESBAQUERO \& E. O. CASAMAYOR. 2005. Does Ecosystem Size Determine Aquatic Bacterial Richness? Ecology, 86(7): 1715-1722

RIDAME, C. \& C. GUIEU. 2002. Saharan input of phosphate to the oligotrophic water of the open 
western Mediterranean Sea. Limnol. Oceanogr., 47(3): 856-869.

RODHE, W. 1948. Environmental requirements of freshwater plankton algae. Experimental studies in the ecology of phytoplankton. Symb. Bot. Ups., 10: 1-149.

SCHLESINGER, W. H. 1997. Biogeochemistry. Academic Press. New York. 588 pp.

STODDARD, J. L., D. S. JEFFRIES, A. LÜKEWILlE, T. A. CLAIR, P. J. DILLON, C. T. DRISCOLL, M. FORSIUS, M. JOHANNESSEN, J. S. KAHL, J. H. KELLOGG, A. KEMP, J. MANNIO, D. T. MONTEITH, P. S. MURDOCH, S. PATRICK, A. REBSDORF, B. L. SKJELKVÅLE, M. P. STAINTON, T. TRAAEN, H. VAN DAM, K. E. WEBSTER, J. WIETING \& A. WILANDER. 1999. Regional trends in aquatic recovery from acidification in North America and Europe. Nature, 401: 575-578.

SULLIVAN. T. J., D. F. CHARLES, J. P. SMOL, B. F. CUMMING, A. R. SELLE, D. R. THOMAS, J. A. BERNERT \& S. S. DIXIT. 1990. Quantification of changes in lakewater chemistry and response to acidic deposition. Nature, 345: 54-58.

TALBOT, R. W., R. C. HARRIS, E. V. BROWELL, G. L. GREGORY, D. I. SEBACHER \& S. M.
BECK. 1986. Distribution and Geochemistry of Aerosols in the Tropical North Atlantic Troposphere: Relationship to Saharan Dust. J. Geophys. Res., 91: 5173-5182.

VOLLENWEIDER, R. A. 1968. Scientific fundamentals of the eutrophications of lakes and flowing waters, with particular reference to nitrogen and phosphorus as factors in eutrophication. OCDE. Paris. Report n ${ }^{\circ}$ DA5/CSI/68.27. 250 pp.

VOLLENWEIDER, R. A. 1975. Input.output models with special reference to the phosphorus loading concept in limnology. Swis J. Hydrd., 37:53-84.

VOLLENWEIDER, R. A. 1976. Advances in defining critical loading levels for phosphorus in lake eutrophication. Mem. Ist. Ital. Idrobiol., 33: 53-83.

WAGENBACH, D. \& K. GEIS. 1989. The mineral dust record in a high alpine glacier (Colle Gniffet, Swiss Alps). In: Paleoclimatology and paleometeorology: modern and past patterns of global atmospheric transport. M., Leinen, and M. Sarnthein (eds.): 543-564. Kluwer Academic Publishing.

WILLEY, J. D., R. J. KIEBER, M. S. EYMAN \& G. B. AVERY. 2000. Rainwater dissolved organic carbon: concentrations and global flux. Global Biogeochemical Cycles, 14: 139-148. 